\title{
Poly(L-lactic acid)/deproteinized natural rubber blends with enhanced compatibility
}

\author{
I Putu Mahendra ${ }^{1), *)}$ (ORCID ID: 0000-0002-0805-4498), Phan Trung Nghia ${ }^{2), 3), ~ *) ~(0000-0002-0805-4498), ~}$ \\ Nguyen Thi Hong Phuong3), Tring Thi Hang ${ }^{3), 4)}$, Nur Fazreen Alias ${ }^{5)}$ (0000-0002-0805-4498), \\ Hanafi Ismail ${ }^{5)}(0000-0003-3474-5265)$
}

\begin{abstract}
PLLA-g-LMWNR (LMWNR - low molecular weight natural rubber) was used as a compatibilizer (1-3 wt \%) of poly(L-lactic acid)/deproteinized natural rubber (PLLA/DPNR) blend (95/5 w/w). The LMWNR was prepared using $\mathrm{TiO}_{2} / \mathrm{ZnO}(9: 1 \mathrm{w} / \mathrm{w})$ and $\mathrm{H}_{2} \mathrm{O}_{2}$ as co-catalyst. The obtained LMWNR was grafted with 0-12 wt \% maleic anhydride (LMWNR-g-MA) and then with PLLA (PLLA- $g$-LMWNR). A significant improvement in the mechanical properties of the PLLA/DPNR blend was found in the blend that contained 3 wt \% PLLA-g-LMWNR. Scanning electron microscopy showed a decrease in the pore diameter from 5.44 to $1.56 \mu \mathrm{m}$. The thermal analysis of PLLA/DPNR blends showed that the $T_{g}$ value of PLLA phase shifted from 63.1 to $61.4^{\circ} \mathrm{C}$. These results confirmed that PLLA-g-LMWNR can enhance the compatibility of the PLLA/DPNR blend.
\end{abstract}

Keywords: compatibility, PLLA, DPNR, low molecular weight, natural rubber, grafting.

\section{Mieszaniny poli(kwas L-mlekowy)/zdeprotonowany kauczuk naturalny o zwiększonej kompatybilności}

Streszczenie: PLLA-g-LMWNR (LMWNR - kauczuk naturalny o małym ciężarze cząsteczkowym) stosowano jako kompatybilizator (1-3\% mas.) mieszaniny PLLA/DPNR [poli(L-kwas mlekowy)/zdeprotonowany kauczuk naturalny] (95/5 w/w). LMWNR otrzymano z DPNR przy użyciu $\mathrm{TiO}_{2} / \mathrm{ZnO}(9: 1 \mathrm{w} / \mathrm{w})$ i $\mathrm{H}_{2} \mathrm{O}_{2}$ jako kokatalizatora, a następnie szczepiono bezwodnikiem maleinowym w ilości $0-12 \%$ mas. (LMWNR-g-MA). PLLA-g-LMWNR uzyskano w wyniku szczepienia PLLA z LMWNR-g-MA. Stwierdzono poprawę właściwości mechanicznych mieszaniny PLLA/DPNR zawierającej 3\% mas. PLLA-g-LMWNR. Metodą SEM wykazano zmniejszenie średnicy porów z 5,44 do 1,56 $\mu \mathrm{m}$. Wartość temperatury zeszklenia $T_{o}$ fazy PLLA mieszaniny PLLA/DPNR, wyznaczona metodą analizy termicznej, zmniejszyła się z 63,1 do $61,4^{\circ} \mathrm{C}$. Uzyskane wyniki potwierdziły, że dodatek PLLA-g-LMWNR zwiększa kompatybilność mieszaniny PLLA/DPNR.

Słowa kluczowe: kompatybilność, PLLA, DPNR, kauczuk naturalny o małym ciężarze cząsteczkowym, szczepienie.

The blending process of two materials, e.g. poly(L-lactic acid) (PLLA) and deproteinized natural rubber (DPNR), which have totally different properties, can produce an

\footnotetext{
1) Program Studi Kimia, Jurusan Sains, Institut Teknologi Sumatera, Jalan Terusan Ryacudu, Way Huwi, Jati Agung, Lampung Selatan 35365, Indonesia

2) Center for Rubber Science and Technology, Hanoi University of Science and Technology, 1 Đại Cồ Việt, Bách Khoa, Hà Nội, Vietnam.

3) School of Chemical Engineering, University of Science and Technology, 1 Đại Cô Việt, Bách Khoa, Hà Nội, Vietnam.

4) Viet Nam Institute for Building Material, 235 Nguyễn Trãi, Thanh Xuân District, Hà Nội, Việt Nam

5) School of Materials and Mineral Resources Engineering, Universiti Sains Malaysia, Transkrian, Nibong Tebal, Seberang Perai Selatan, Penang, Malaysia

*) Authors for correspondence: i.mahendra@ki.itera.ac.id, nghia.phantrung@hust.edu.vn
}

immiscible blend that mostly leads to incompatibility issues $[1,2]$. An immiscible blend can be obtained due to the differences in polarity of the materials, here PLLA and DPNR. As a consequence, numerous studies have been conducted to enhance the properties of PLLA/DPNR blends by incorporating several kinds of additive, i.e. compatibilizer and natural fibers. However, the use of MA (maleic anhydride) grafted polymer, epoxidized natural rubber, acrylated natural rubber, and liquid natural rubber as compatibilizers, as well as natural fibers, i.e. cellulosic based products, cannot overcome those compatibility issues [2-7].

Several previous studies were performed to obtain a graft of PLLA- $g$-DPNR by a direct process in the presence of catalyst. The earliest study of PLLA- $g$-DPNR was prepared using low molecular weight PLLA and ribbed, smoked natural rubber that had been grafted with MA without any catalyst added to the system [8]. This study was followed by others with an improved method in 
which the catalyst 4-dimethylaminopyridine (DMAP) and tin octoate $(\mathrm{TO})$ was added to the system $[3,9,10]$. Instead of using a solvent system, grafted PLLA- $g$-DPNR without grafted MA was also prepared through a meltblending technique in the presence of dicumyl peroxide (DCP) and Irganox 1010 [11, 12].

The grafted PLLA with low molecular weight deproteinized natural rubber and its effect on the mechanical, morphology, and thermal properties of the PLLA/DPNR blends has not been evaluated. Low molecular weight natural rubber (LMWNR) has a shorter chain than untreated natural rubber, and this can increase the probability of the grafting reaction between PLLA and natural rubber. As an assumption, the direct effect will result in the improvement of the grafting degree of PLLA- $g$ -DPNR, and the compatibility of PLLA/DPNR blends. Thus, the objective of this study was to evaluate and determine the role of PLLA- $g$-LMWNR as a compatibilizer for PLLA/DPNR blends [95/5 w/w]. The compatibilized PLLA/DPNR blends were compared with the uncompatibilized and maleated PLLA/DPNR blends.

\section{EXPERIMENTAL PART}

\section{Materials}

Poly(L-lactic acid) (PLLA) 4032D was produced by Natureworks ${ }^{\circledR}$ LLC (Minnentoka, Minnesota). The catalyst of 4-dimethylaminopyridine (DMAP, $\mathrm{C}_{7} \mathrm{H}_{10} \mathrm{~N}_{2}$ ), the monomer of maleic anhydride $\left(\mathrm{MA}, \mathrm{C}_{4} \mathrm{H}_{2} \mathrm{O}_{3}\right)$, dicumyl peroxide (DCP, $\mathrm{C}_{18} \mathrm{H}_{22} \mathrm{O}_{2}$ ), zinc oxide ( $\mathrm{ZnO}$ ), sodium dodecyl sulfate (SDS, $\mathrm{C}_{12} \mathrm{H}_{25} \mathrm{SO}_{4} \mathrm{Na}$ ) and hydrogen peroxide $\left(\mathrm{H}_{2} \mathrm{O}_{2}\right)$ were purchased from Sigma Aldrich (Singapore). High ammonia natural rubber latex (HANR, dry rubber content $=60.0 \%$ ) was obtained from a rubber plantation in Thanh Hoa Province, Vietnam. Titanium dioxide $\left(\mathrm{TiO}_{2}\right)$ was obtained from our previous study [13].

\section{Preparation of low molecular weight deproteinized natural rubber (LMWNR) latex}

The obtained DPNR prepared using the Kawahara method [14] was treated in a photocatalytic chamber in the presence of $2 \mathrm{phr}$ (parts per hundred resin) of SDS, $0.8 \mathrm{phr}$ of $\mathrm{TiO}_{2} / \mathrm{ZnO}(9: 1 \mathrm{w} / \mathrm{w})$ and $10 \mathrm{phr}$ of $\mathrm{H}_{2} \mathrm{O}_{2} 30 \mathrm{wt} \%$. The photocatalytic treatment was performed for $48 \mathrm{~h}$. Centrifugation was performed at the end of the process to separate out the undissolved material. The obtained latex was dried at a temperature of $60^{\circ} \mathrm{C}$ until a constant weight was obtained.

\section{Preparation of maleic anhydride grafted natural rubber (LMWNR-g-MA)}

The obtained dried LMWNR was dissolved in toluene $\left(1 \mathrm{~g}: 10 \mathrm{~cm}^{3}\right)$ at a temperature of $80^{\circ} \mathrm{C}$ and mixed at $600 \mathrm{rpm}$. The solution of MA was added drop wise into the LMWNR solution over 10 min after adding $2 \mathrm{wt} \% \mathrm{DCP}$, the amount of loaded MA was varied, i.e. $0-12.0 \mathrm{wt} \%$, depending on the final formulation. After two hours, the grafting reaction was stopped by the addition of a small drop of water. The separation of the grafted natural rubber was performed by precipitation into a mixture of acetone/methanol. The obtained product was labeled as LMWNR-g-MA-1, LMWNR-g-MA-3, LMWNR-g-MA-12 (the number at the end of the labeled product notes the MA content of the grafted product).

\section{Preparation of poly(L-lactic acid) grafted natural rubber (PLLA-g-LMWNR)}

The grafted PLLA-g-LMWNR was prepared using a solvent system, toluene, at $120^{\circ} \mathrm{C}$ for $24 \mathrm{~h}$ with mixing at $600 \mathrm{rpm}$. The ratio of PLLA and LMWNR-g-MA was $1: 1$ (based on weight ratio), and 0.0380 mole of the $\mathrm{N}$-catalyst. The obtained PLLA-g-LMWNR was placed in the fume hood to evaporate the toluene [9]. The obtained product was labeled as PLLA- $g$-LMWNR-1, PLLA- $g$-LMWNR-3, and PLLA-g-LMWNR-12 (the number at the end of the labeled product notes the MA content of the LMWNR used for preparing PLLA- $g$-LMWNR).

\section{Preparation of PLLA/DPNR blends}

The blends of PLLA/DPNR (Table 1) were prepared using a Labo Plastomil 4M150 (Toyoseiki) at $50 \mathrm{rpm}$, with maximum loading capacity of $35 \mathrm{~g}$. The processing condition was set at $180^{\circ} \mathrm{C}$ with 15 minutes blending time. The blending process of PLLA, PLLA- $g$-LMWNR and DPNR was carried out by loading PLLA pellets into the chamber. After 6 minutes, the PLLA was molten, then PLLA-g-LMWNR and DPNR were added for another 9 minutes, and the blending process was stopped when the torque value showed a constant value [15].

\section{Methods of testing}

- The functional groups of the rubber samples, before and after treatment, were determined using a FT-IR-6300 (Jasco Inc., Japan).

- The weight-average molecular weight $\left(M_{w}\right)$ of the low molecular weight natural rubber was determined using a Viscotek multi-detector gel permeation chromatograph (GPC, Malvern, UK), the measurement was carried out at $30^{\circ} \mathrm{C}$ using tetrahydrofuran (THF) as the mobile phase and polyisoprene as the internal standard.

- The mechanical properties (tensile strength, Young's modulus, and elongation at break) of compatibilized and uncompatibilized PLLA/DPNR blends were evaluated using a Strograph VG5E (Toyoseiki, Japan) equipped with a $5 \mathrm{kN}$ load cell at a speed of $10 \mathrm{~mm} / \mathrm{min}$.

- The hardness properties of PLLA/DPNR blends were determined using a durometer GS-709N Type A (Teclock, Japan) equipped with a $1 \mathrm{~kg}$ load cell. 
$\mathrm{T}$ a b 1 e 1. The formulation of PLLA/DPNR blends

\begin{tabular}{|c|c|c|c|}
\hline $\begin{array}{l}\text { PLLA } \\
\text { wt } \%\end{array}$ & $\begin{array}{l}\text { DPNR } \\
\text { wt } \%\end{array}$ & $\begin{array}{c}\text { PLLA- } g \text {-LMWNR* } \\
\text { wt } \%\end{array}$ & Code \\
\hline \multicolumn{4}{|c|}{${ }^{*}$ from LMWNR-g-MA 1\% } \\
\hline 94.05 & 4.95 & 1.00 & 1\% PLLA/DPNR/PLLA-LMWNR-1 \\
\hline 93.10 & 4.90 & 2.00 & 2\% PLLA/DPNR/PLLA-LMWNR-1 \\
\hline 92.15 & 4.85 & 3.00 & 3\% PLLA/DPNR/PLLA-LMWNR-1 \\
\hline \multicolumn{4}{|c|}{ *from LMWNR-g-MA 3\% } \\
\hline 94.05 & 4.95 & 1.00 & 1\% PLLA/DPNR/PLLA-LMWNR-3 \\
\hline 93.10 & 4.90 & 2.00 & 2\% PLLA/DPNR/PLLA-LMWNR-3 \\
\hline 92.15 & 4.85 & 3.00 & 3\% PLLA/DPNR/PLLA-LMWNR-3 \\
\hline \multicolumn{4}{|c|}{${ }^{*}$ from LMWNR-g-MA $12 \%$} \\
\hline 94.05 & 4.95 & 1.00 & 1\% PLLA/DPNR/PLLA-LMWNR-12 \\
\hline 93.10 & 4.90 & 2.00 & 2\% PLLA/DPNR/PLLA-LMWNR-12 \\
\hline 92.15 & 4.85 & 3.00 & 3\% PLLA/DPNR/PLLA-LMWNR-12 \\
\hline
\end{tabular}

- The morphological analysis of the fractured surface of specimens was captured using a scanning electron microscope Nova NanoSEM 450 (Nova, USA).

- The thermal properties of the blends were examined using a DTG-60 Shimadzu with temperature ranging from $30-600^{\circ} \mathrm{C}$ at a heating rate of $10^{\circ} \mathrm{C} / \mathrm{min}$.

\section{RESULTS AND DISCUSSION}

\section{Photodegradation of deproteinized natural rubber}

The photocatalysis of deproteinized natural rubber latex using a composite of $\mathrm{TiO}_{2} / \mathrm{ZnO}$, and the presence of $\mathrm{H}_{2} \mathrm{O}_{2}$ showed a satisfactory result for the reduction of the natural rubber molecular weight. The presence of UV light during photocatalysis caused photon migration that generated holes and electrons on the surfaces of the photocatalyst materials. The photodegradation of DPNR in the presence of $\mathrm{TiO}_{2} / \mathrm{ZnO}$ composite and $\mathrm{H}_{2} \mathrm{O}_{2}$ can be considered as the photolysis of $\mathrm{C}_{1}-\mathrm{C}_{2}$ and $\mathrm{C}_{3}-\mathrm{C}_{4}$ carboncarbon bonds, or the case of $\mathrm{C}_{2}-\mathrm{C}_{5}$ (Scheme $\mathrm{A}$ ), which then causes direct cleavage of the DPNR.

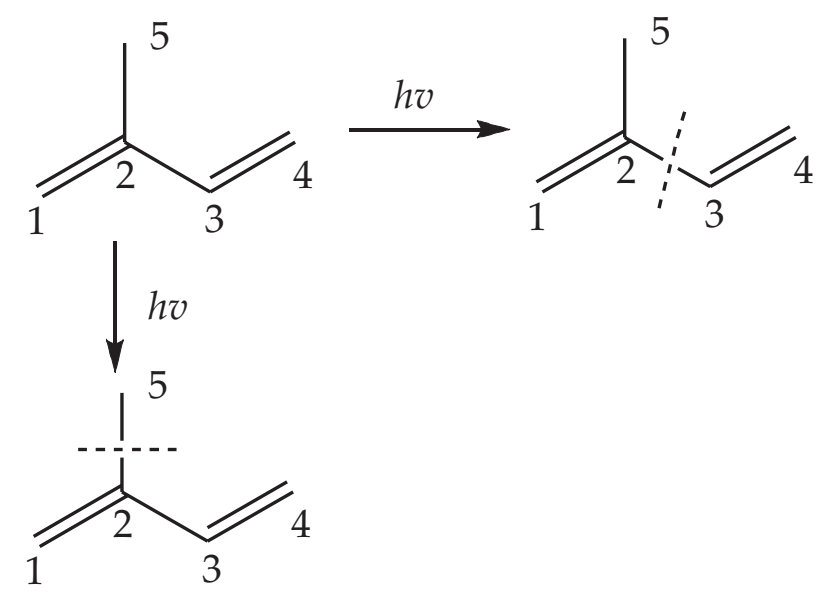

Scheme A
Table 2 shows the molecular weight of deproteinized natural rubber before and after photocatalysis. In the presence of composite $\mathrm{TiO}_{2} / \mathrm{ZnO}$, the molecular weight of deproteinized natural rubber was reduced to $15.8 \cdot 10^{3} \mathrm{kDa}$ with a polydispersity of 3.6. Generally, both FT-IR spectra of DPNR and LMWNR (Fig. 1) showed a quite similar pattern.

T a b l e 2. Molecular weight of deproteinized natural rubber

\begin{tabular}{c|c|c|c|c}
\hline Sample & $\begin{array}{c}M_{n} \\
10^{3} \cdot \mathrm{kDa}\end{array}$ & Polydispersity & $\begin{array}{c}\text { Gel content } \\
\%\end{array}$ & $\begin{array}{c}\mathrm{C}=\mathrm{C} \text { band } \\
\text { area }\end{array}$ \\
\hline DPNR & 549.30 & 7.50 & 19.2 & 0.7956 \\
LMWNR & 15.80 & 3.60 & 0.49 & 0.7626 \\
\hline
\end{tabular}

There was a depletion and increase in some bands indicating the breaking of chains. Due to the similarity of these spectra, the observation was based on the difference of band areas (Table 2). The bands for the $\mathrm{C}=\mathrm{C}$ and $\mathrm{C}=\mathrm{O}$ bonds from both spectra were used as references because changes of these peaks have been found after degradation. In Table 2, the band area of $C=C$ of LMWNR had a lower value than the signals in DPNR.

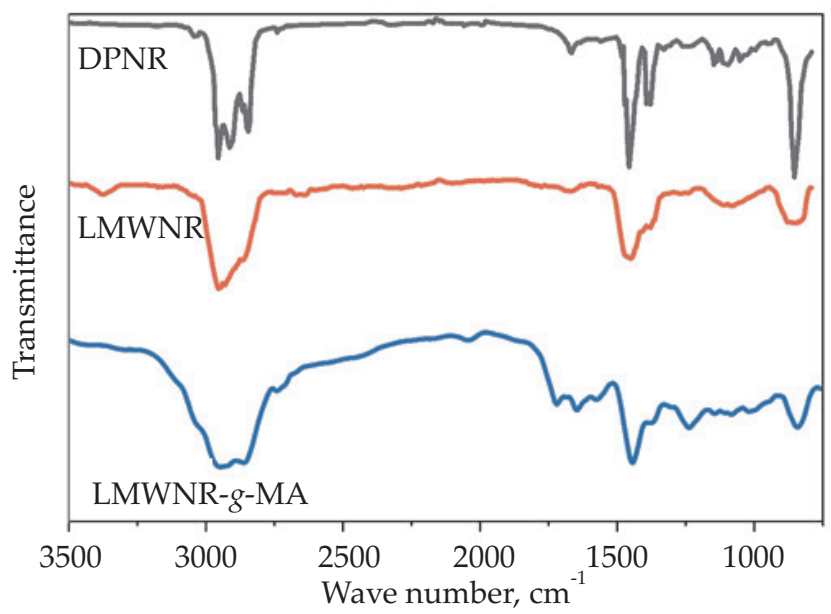

Fig. 1. FT-IR spectra of DPNR and modified DPNR 


\section{Modification of LMWNR through a grafting process}

The modification of LMWNR was performed through a grafting process using 1.0-12.0 wt \% of MA in the presence of DCP as an initiator. The presence of the MA group in the LMWNR was confirmed by the presence of an additional peak around $1700 \mathrm{~cm}^{-1}$ attributed to the $\mathrm{C}=\mathrm{O}$ stretching vibration of MA. The grafting degree had a linear correlation and slightly increased within the amount of MA that was added during the reaction (Fig. 2). A similar result was also obtained in several studies that prepared polymer grafted MA [5, 16, 17].

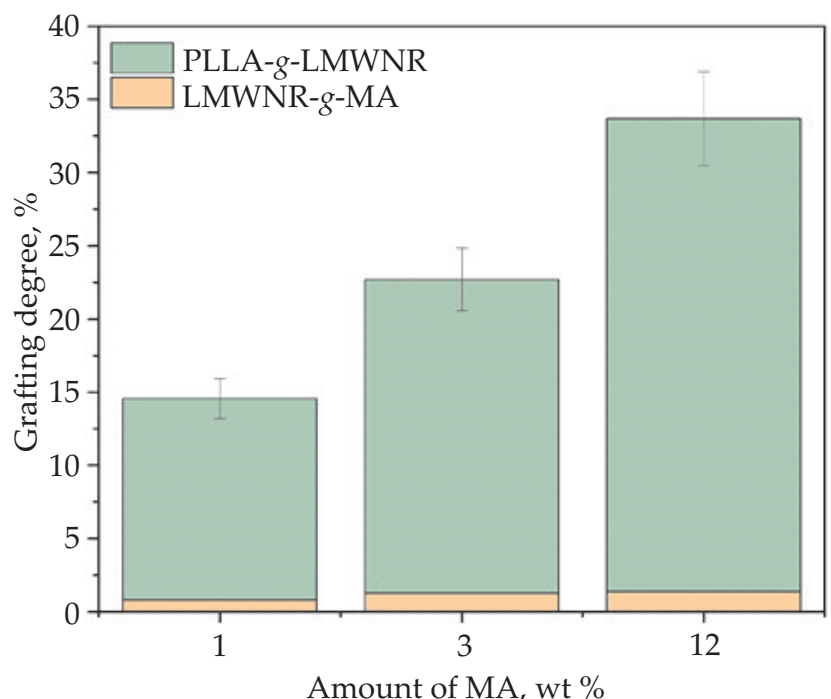

Fig. 2. Grafting degree of LMWNR-MA and PLLA-LMWNR

The esterification of LMWNR-g-MA and PLLA was performed at a ratio of $1: 1$ with the presence of $\mathrm{N}$-catalyst. In LMWNR-g-MA, the IR spectra show absorbance bands at 1778 and $1853 \mathrm{~cm}^{-1}$, which correspond to the symmetric and asymmetric anhydride ring $\mathrm{C}=\mathrm{O}$ vibrations, respectively. Thereafter, PLLA was grafted onto LMWNR-g-MA in toluene solvent at a temperature of $120^{\circ} \mathrm{C}$. The complete grafting was proved by FT-IR. As seen, the IR absorption band at $1853 \mathrm{~cm}^{-1}$, corresponding to the anhydride moiety, disappears (see Fig. 1). The increase of PLLA-g-LMWNR's grafting degree showed a linear correlation to the content of MA in LMWNR-g-MA.

\section{Characteristics of PLLA/DPNR blends in the presence of PLLA- $g$-LMWNR}

The effect of PLLA- $g$-LMWNR as a compatibilizer on the mechanical properties of PLLA/DPNR blends can be seen in Fig. 3.

The addition of PLLA- $g$-LMWNR to PLLA/DPNR (95/5) blends significantly increase the toughness value. The toughness value was determined from the value of area under the strain $v s$. stress curve that was obtained during tensile testing. The highest toughness value was obtained in the presence of $3.0 \mathrm{wt} \%$ PLLA- $g$-LMWNR, which was prepared from LMWNR that contained $3.0 \mathrm{wt} \%$ MA. The improvement of toughness value by the presence of PLLA- $g$-LMWNR can be explained as the effect of a bridge structure [15]. A phase separation was observed in the PLLA/DPNR blend without the addition of any PLLA-g-LMWNR (Fig. 4a), which is shown with spherical pores of varied diameter. This kind of morphology is commonly obtained in a blend that is not compatible [18-21]. Table 3 shows the summarized data of the DPNR's spherical pores. In the case of PLLA/DPNR without any compatibilizer, the diameter and diameter distribution $(\sigma)$ parameters were $5.44 \mu \mathrm{m}$ and 1.99, respectively. After the addition of compatibilizer, PLLA- $g$-LMWNR, the PLLA/DPNR blends exhibited little homogeneity in the morphology of the fracture surface. Significant changes were observed in the diameter and diameter distribution parameter of spherical pores, e.g. 1.56-2.27 $\mu \mathrm{m}$ and 0.76-1.41, respectively.

A decrease of the pore size after the addition of compatibilizer was also observed in several previous studies $[9,10,22]$. This also has a direct effect on the improvement of the mechanical properties of blends. The tensile, Young's modulus and elongation at break of PLLA/DPNR blends that were compatibilized in the presence of PLLA- $g$-LMWNR showed a significant improvement. This result was quite different from the previous study that used PLLA-g-DPNR as the compatibilizer. In that study, the mechanical properties of compatibilized PLLA/DPNR blends had a similar value with the uncompatibilized blends and cavities found after mechanical testing. The formation of these cavities on the blend surface confirmed that the interaction of natural rubber itself

T a b l e 3. Diameter of spherical pores and their distribution parameter

\begin{tabular}{|c|c|c|}
\hline Sample & Diameter, $\mu \mathrm{m}$ & $\begin{array}{l}\text { Diameter } \\
\text { distribution }\end{array}$ \\
\hline PLLA/DPNR & 5.44 & 1.99 \\
\hline 3\% PLLA/DPNR/PLLA-LMWNR-1 & 2.15 & 1.13 \\
\hline 3\% PLLA/DPNR/PLLA-LMWNR-3 & 1.56 & 0.76 \\
\hline 3\% PLLA/DPNR/PLLA-LMWNR-12 & 2.27 & 1.41 \\
\hline
\end{tabular}




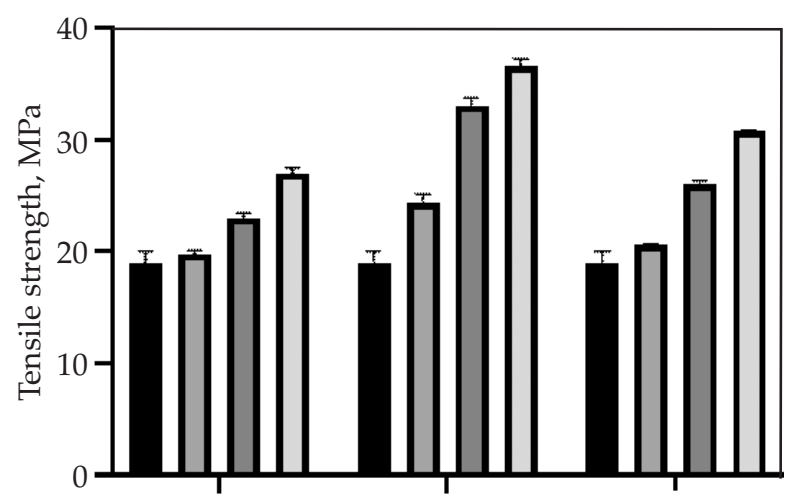

LMWNR-1 LMWNR-3 LMWNR-12

PLLA/DPNR/PLLA-LMWNR blends
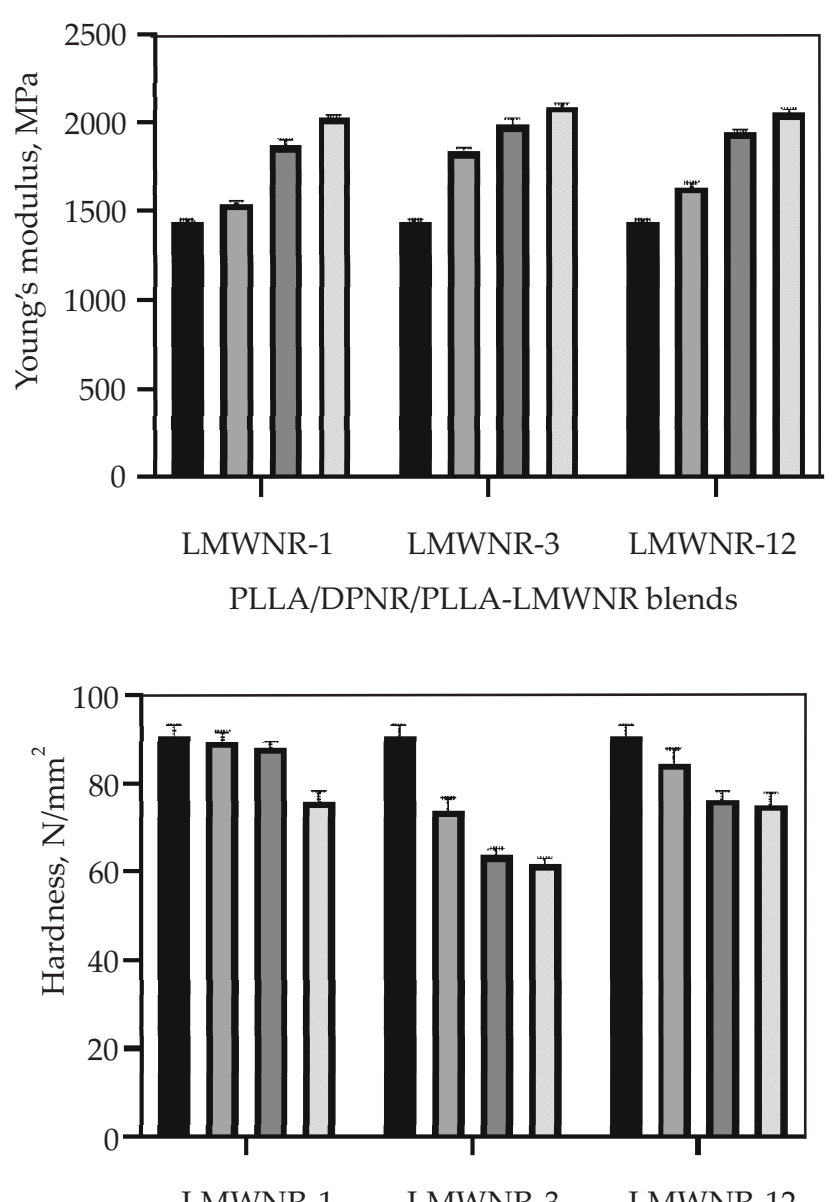

PLLA/DPNR/PLLA-LMWNR blends

Fig. 3. Mechanical properties of PLLA/DPNR blends

and the compatibilizer in these blends were not enough to act as an absorber for reducing the stress obtained from the load during testing. This implied that the use of PLLA-g-LMWNR was more effective than PLLA- $g$-DPNR to enhance the compatibility of PLLA/DPNR blends.

The thermal properties of PLLA, PLLA/DPNR and the blends that were compatibilized with PLLA-g-LMWNR are comparatively summarized in Fig. 5 and Table 4.

The addition of PLLA- $g$-LMWNR into the PLLA/DPNR blends increased the decomposition temperature to
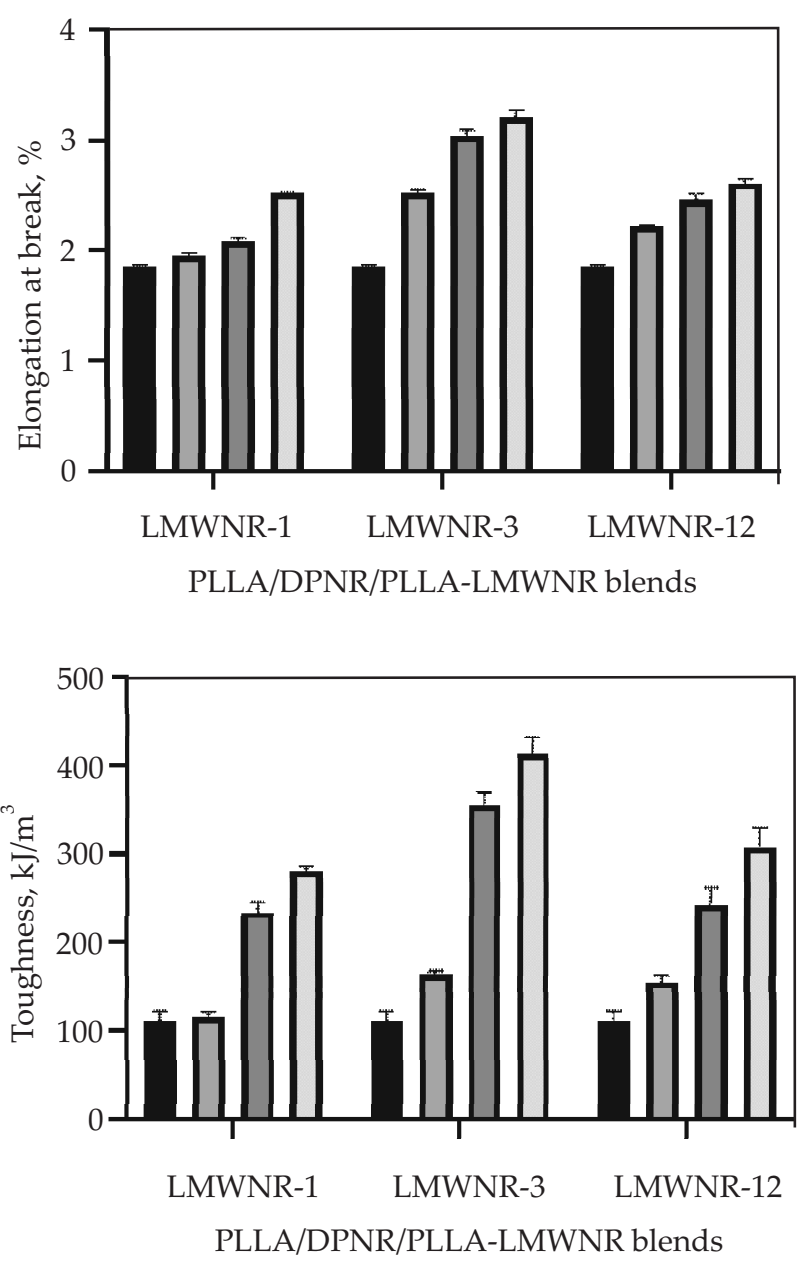

$0 \%$
$1 \%$
口 $2 \%$
$3 \%$

$349^{\circ} \mathrm{C}$ and $366^{\circ} \mathrm{C}$. This result proved that the addition of PLLA-g-LMWNR could enhance the thermal stability of PLLA/DPNR blends; this data also showed a linear result to the morphological property of the blends, PLLA- $g$-LMWNR also could improve the homogeneity between the PLLA and DPNR phases. The $T_{g}$ values of the PLLA phases in the compatibilized PLLA/DPNR blends shifted to the left position or lower value. This kind of shift was also observed in other compatibilized blends, i.e. PLLA/NR [9], PP/CNR [15], LLDPE/Nylon-6 


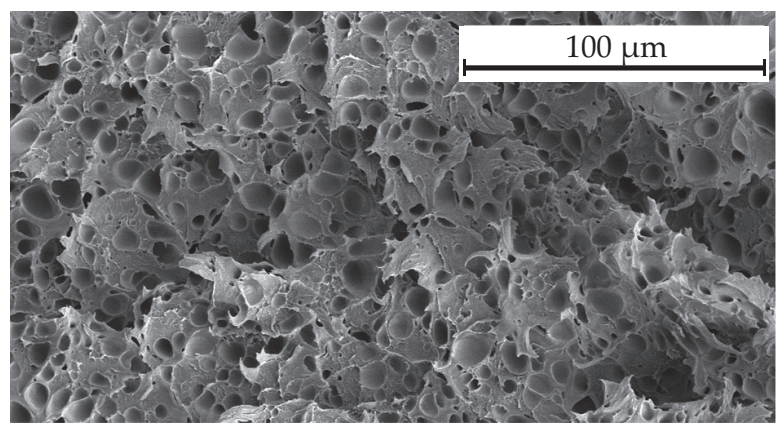

c)

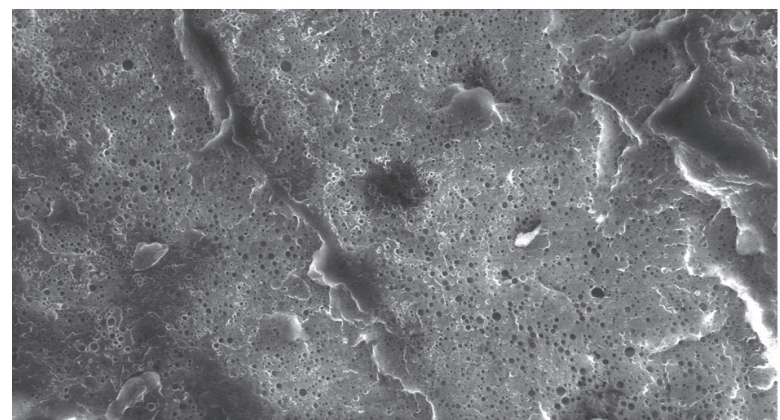

b)

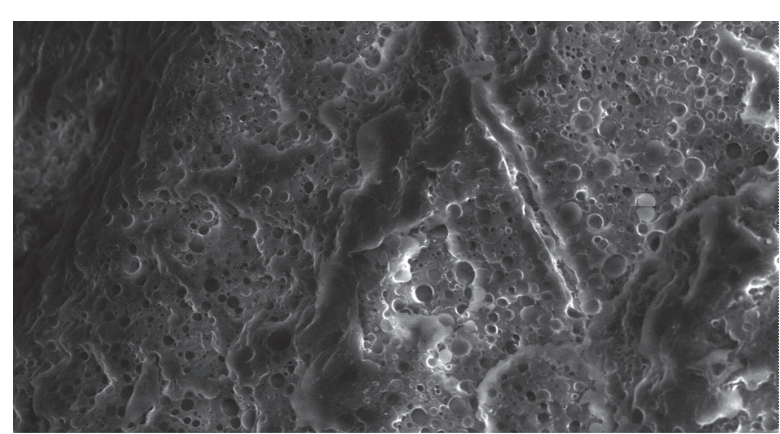

d)

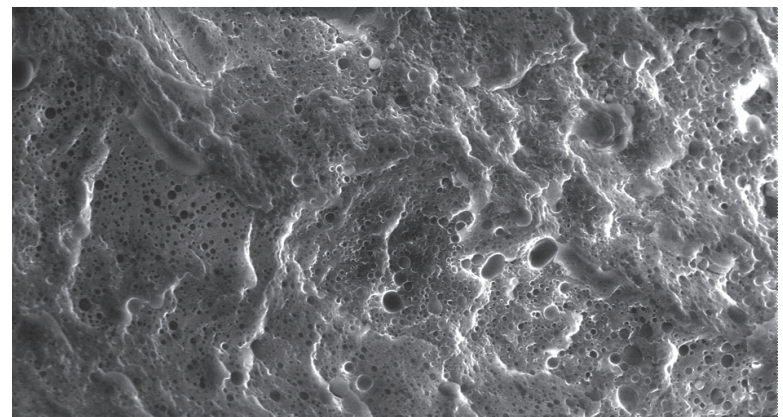

Fig. 4. Fracture surface morphology of: a) PLLA/DPNR, b) 3\% PLLA/DPNR/PLLA-LMWNR-1, c) 3\% PLLA/DPNR/PLLA-LMWNR-3, d) 3\% PLLA/DPNR/PLLA-LMWNR-12
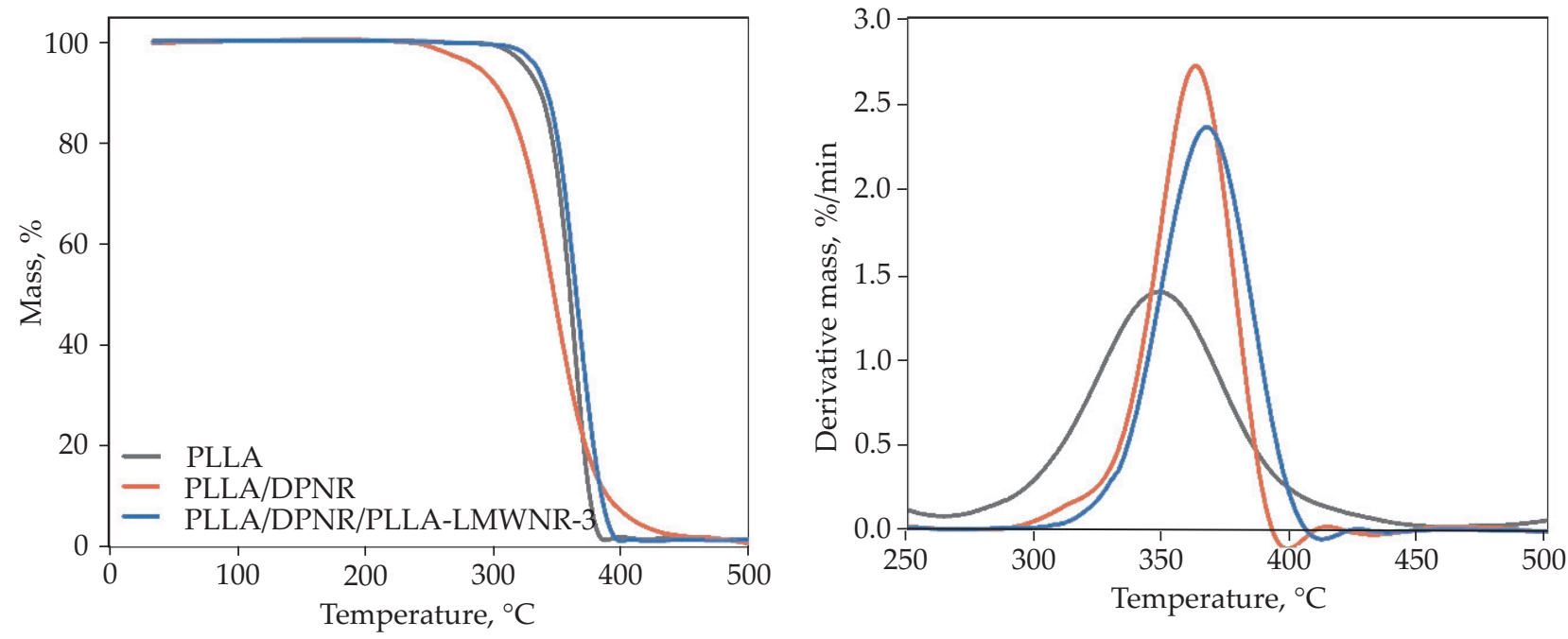

Fig. 5. TGA and DTG curves of PLLA blends

T a b l e 4. Thermal stability of PLLA blends

\begin{tabular}{|c|c|c|}
\hline Sample & $T_{\text {max }^{\prime}}{ }^{\circ} \mathrm{C}$ & $T_{g}$ of PLLA phase, ${ }^{\circ} \mathrm{C}$ \\
\hline PLLA & 362.63 & 63.51 \\
\hline PLLA/DPNR & 349.69 & 63.14 \\
\hline 3\% PLLA/DPNR/PLLA-LMWNR-3 & 366.33 & 61.40 \\
\hline
\end{tabular}


[23], and PLLA/PBAT/PLLA [24] that also indicated that the addition of PLLA- $g$-LMWNR as compatibilizer could induce the formation of a miscible blend between PLLA and DPNR.

\section{CONCLUSIONS}

The PLLA- $g$-LMWNR-3 that we prepared from LMWNR, which has 3 wt \% of MA content (LMWNR-g-MA 3\%), was able to improve the mechanical properties of PLLA/DPNR blends, including tensile strength, Young's modulus, elongation at break, and toughness, but the hardness was decreased as the PLLA-g-LMWNR amount added to the blends increased. The SEM images confirmed the positive effect of the incorporation of compatibilizer, the spherical pore size of natural rubber was found to be smaller, indicating a better dispersion of DPNR in the PLLA matrix. The addition of PLLA- $g$-LMWNR into the PLLA/DPNR blends gave a slight reduction of $T_{g}$ for the PLLA phase. It can be assumed that the presence of compatibilizer induced the formation of a miscible blend between PLLA and DPNR.

\section{ACKNOWLEDGMENTS}

This work has been supported by RoHan Project funded by the German Academic Exchange Service (DAAD, No. 57315854) and the Federal Ministry for Economic Cooperation and Development (BMZ) inside the framework "SDG Bilateral Graduate school programme".

\section{REFERENCES}

[1] Pongtanayut K., Thongpin C., Santawitee O.: Energy Procedia 2013, 34, 888. http://dx.doi.org/10.1016/j.egypro.2013.06.826

[2] Jaratrotkamjorn R., Khaokong C., Tanrattanakul V.: Journal of Applied Polymer Science 2012, 124 (6), 5027. http://dx.doi.org/10.1002/app.35617

[3] Wongngam Y., Pattamaprom C.: Defect and Diffusion Forum 2018, 382, 7.

http://dx.doi.org/10.4028/www.scientific.net/ DDF.382.7

[4] Rosli N.A., Ahmad I., Anuar F.H., Abdullah I.: Cellulose 2019, 26 (5), 3205. http://dx.doi.org/10.1007/s10570-019-02262-x

[5] Abdullah Sani N.S., Arsad A., Rahmat A.R.: Applied Mechanics and Materials 2014, 554, 96. http://dx.doi.org/10.4028/www.scientific.net/ AMM.554.96

[6] Mohammad N.N.B., Arsad A., Rahmat A.R. et al.: Polymer Science Series A 2016, 58 (2), 177. http://dx.doi.org/10.1134/S0965545X16020164

[7] Alias N.F., Ismail H., Ishak K.M.K.: Materials Today: Proceedings 2019, 17, 584. http://dx.doi.org/10.1016/j.matpr.2019.06.338

[8] Thepthawat A., Srikulkit K.: Polymer Engineering and Science 2014, 54 (12), 2770. http://dx.doi.org/10.1002/pen

[9] Sookprasert P., Hinchiranan N.: Journal of Materials Research 2017, 32 (4), 788. http://dx.doi.org/10.1557/jmr.2017.9

[10] Sookprasert P., Hinchiranan N.: Macromolecular Symposia 2015, 354 (1), 125. http://dx.doi.org/10.1002/masy.201400106

[11] Yuan D., Chen K., Xu C. et al.: Carbohydrate Polymers 2014, 113, 438. http://dx.doi.org/10.1016/j.carbpol.2014.07.044

[12] Yuan D., Xu C., Chen Z., Chen Y.: Polymer Testing 2014, 38, 73.

http://dx.doi.org/10.1016/j.polymertesting.2014.07.004

[13] Mahendra I.P., Huda A., Ngoc H.M. et al.: Journal: Arab Journal of Basic and Applied Sciences 2019, 26, 1. http://dx.doi.org/10.1080/25765299.2019.1610209

[14] Yamamoto Y., Nghia P.T., Klinklai W. et al.: Journal of Applied Polymer Science 2008, 107 (4), 2329. http://dx.doi.org/10.1002/app.27236

[15] Mahendra I.P., Wirjosentono B., Tamrin Ismail H. et al:: Journal of Polymer Research 2019, 26, 9. http://dx.doi.org/10.1007/s10965-019-1878-2

[16] García-López D., Gobernado-Mitre I., Merino J.C., Pastor J.M.: Polymer Bulletin 2007, 59 (5), 667. http://dx/doi/org/10.1007/s00289-007-0810-9

[17] dos Anjos E.G.R., Backes E.H., Marini J. et al.: Journal of Polymer Research 2019, 26, 134. https://doi.org/10.1007/s10965-019-1800-y

[18] Fu Z., Wang H., Zhao X. et al.: Polymer 2017, 132, 353. http://dx.doi.org/10.1016/J.POLYMER.2017.11.004

[19] Cao Y., Zhang J., Feng J., Wu P.: ACS Nano 2011, 5 (7), 5920. http://dx.doi.org/10.1021/nn201717a

[20] Martin J.D., Velankar S.S.: Journal of Rheology 2007, 51 (4), 669. http://dx.doi.org/10.1122/1.2742391

[21] Barlow J.W., Paul D.R.: Polymer Engineering and Science 1984, 24 (8), 525. http://dx.doi.org/10.1002/pen.760240804

[22] Bitinis N., Verdejo R., Cassagnau P., Lopez-Manchado M.A.: Materials Chemistry and Physics 2011, 129, 823. http://dx.doi.org/10.1016/j.matchemphys.2011.05.016

[23] Das V., Kumar V., Singh A. et al:: Polymer-Plastics Technology and Engineering 2012, 51 (5), 446. http://dx.doi.org//10.1080/03602559.2011.639840

[24] Ding Y., Lu B., Wang P. et al.: Polymer Degradation and Stability 2018, 147, 41. http://dx.doi.org/10.1016/j.polymdegradstab.2017.11.012 Received 14 IV 2020. 